\title{
Seven Years Leptospirosis Follow-Up in a Critical Care Unit of a French Metropolitan Hospital; Role of Real Time PCR for a Quick and Acute Diagnosis
}

\author{
Olivier Bahuaud ${ }^{1,2}\left(\mathbb{D}\right.$, Adeline Pastuszka ${ }^{1,3}$, Cécile Le Brun ${ }^{1}$, Stephan Ehrmann ${ }^{2,4}$ and \\ Philippe Lanotte ${ }^{1,3, *}$ \\ 1 Service de Bactériologie-Virologie, CHRU de Tours, 37044 Tours, France; olivier.bahuaud@gmail.com (O.B.); \\ adeline.pastuszka@chu-tours.fr (A.P.); C.LEBRUN@chu-tours.fr (C.L.B.) \\ 2 Service de Médecine Intensive Réanimation, INSERM CIC 1415, CRICS-TriggerSep Research Network, \\ F37044 Tours, France; stephanehrmann@gmail.com \\ 3 UMR1282 Infectiologie et Santé Publique, INRA-Université de Tours, F-37380 Nouzilly, France \\ 4 Centre d'étude des pathologies respiratoires, INSERM U1100, Université de Tours, F37000 Tours, France \\ * Correspondence: philippe.lanotte@univ-tours.fr; Tel.: + 33-(0)2-4747-4796; Fax: +33-(0)2-4747-3812
}

Received: 18 August 2020; Accepted: 8 September 2020; Published: 18 September 2020

\begin{abstract}
Background: Leptospirosis infection can lead to multiple organ failure, requiring hospitalization in an intensive care unit for supportive care, along with initiation of an adapted antibiotic therapy. Achieving a quick diagnosis is decisive in the management of these patients. (2) Methods: We present here a review of leptospirosis cases diagnosed in the intensive care unit of our hospital over seven years. Clinical and biological data were gathered, and we compared the differences in terms of diagnostic method. (3) Results: Molecular biology method by Polymerase Chain Reaction (PCR) allowed quick and reliable diagnosis when performed in the first days after the symptoms began. Moreover, we identified that sampling blood and urine for PCR was more efficient than performing PCR on only one type of biological sample. (4) Conclusions: Our results confirm the efficiency of PCR for the quick diagnosis of leptospirosis and suggest that testing both blood and urine early in the disease might improve diagnosis.
\end{abstract}

Keywords: leptospirosis; intensive care unit; polymerase chain reaction; diagnosis

\section{Introduction}

Leptospirosis is a widespread bacterial zoonosis caused by pathogenic Leptospira species. It is responsible for large epidemics in endemic tropical areas. The global burden of Leptospirosis is estimated at one million cases with approximately 60,000 deaths annually, occurring primarily in rural and peri-urban areas of tropical regions [1]. Although the impact of the disease is lower in developed countries, metropolitan France has one of the highest incidence rates among these countries [2]. Humans serve as accidental hosts and small mammals, mainly rodents, constitute the major reservoir. Leptospira colonize their urinary tract, thus inducing urinary shedding that can last for long periods without symptoms. Infection occurs either through direct contact with infected animals, or indirectly via mucous membranes or skin lesions that have been in contact with soil or water contaminated with urine from infected animals [3,4].

Clinical features of leptospirosis regroup a broad spectrum of symptoms [4]. Patients typically present with brutal onset of fever and non-specific symptoms such as chills, muscle pain and headache [3,4]. The typical association of jaundice and kidney failure is known as Weil's disease. Conjunctival suffusion is also common during leptospirosis [5]. Pulmonary and/or abdominal symptoms are often involved in these patients, including severe cough, dyspnea, cholecystitis and 
pancreatitis. Thrombocytopenia occurs frequently and although it does not usually cause spontaneous bleeding, patients can develop severe gastrointestinal or pulmonary hemorrhage [4]. Leptospirosis can also be responsible for severe infections leading to multiple organ dysfunctions including brain, lung, liver and kidney failure. In these cases, admission to an Intensive Care Unit (ICU) and provision of vital support is required, along with an adapted antimicrobial therapy such as aminopenicillin, third generation cephalosporins or doxycycline [6].

Diagnosis is confirmed after biological identification of the pathogen. Conventional diagnosis was initially based on culturing and observing Leptospira by dark field microscopy; however, given the fastidious culture characteristic, direct identification has been replaced by serological diagnosis based on detection of anti-Leptospira antibodies by Microscopic Agglutination Test (MAT), considered a gold standard technique [7]. However, the delay between the onset of the disease and the detectability of the anti-Leptospira antibodies represents a downside of this method. Indeed, the serological confirmation often comes well after the beginning of the symptoms, which is in contrast with the necessity of an accurate diagnosis, which would allow the initiation of an adapted therapy as early as possible. Molecular detection methods now allow detection and genotyping of the pathogen in the early phase of the disease [8-12]. Current guidelines recommend testing either blood, urine or cerebrospinal fluid (CSF) depending on the delay since the first symptoms [6,7]. Several quantitative PCR (Polymerase Chain Reaction) assays have been described that target different genes [9,13-17]. Merien et al. have designed a PCR assay that targets the specific gene lfbl (encoding leptospira fibronectin binding protein 1), conserved among the pathogenic leptospira species, allowing early diagnosis from blood samples [17]. Our laboratory uses this lfb1 PCR assay to diagnose leptospirosis in patients. Here we present a review of leptospirosis cases, diagnosed by a molecular approach using the lfb1 PCR on blood, urine and/or CSF samples between January 2011 and January 2018 in the University Hospital of Tours, France.

\section{Experimental Section}

\subsection{Study Design}

We carried out a monocentric review of severe leptospirosis cases hospitalized in the ICU at the University Hospital of Tours (France) occurring between January 2011 and January 2018. Patients presenting with clinical, biological and/or epidemiological data evocative of leptospirosis, associated with a positive molecular or serological testing, were considered as confirmed cases and included in this study.

\subsection{Real-Time PCR Method}

The real-time PCR method was adapted from Merien et al. and Bourhy et al. [9,17]. The in-house PCR assay targeted the lfb1 gene. Samples were either blood collected on EDTA, urine or CSF, or tissue from a solid organ biopsy performed during autopsy. Pretreatment of the samples was required for DNA extraction from urine, blood, tissues and CSF samples. For urine samples, $1 \mathrm{~mL}$ of urine was centrifugated for $5 \mathrm{~min}$ at $3000 \mathrm{rpm}$, the supernatant was discarded, and the pellet was resuspended by adding $1 \mathrm{~mL}$ PBS (Sigma Aldrich, Saint Louis, USA). After a new step of centrifugation, the supernatant was discarded and the pellet was resuspended by adding $200 \mu \mathrm{L}$ G2 (Qiagen, Hilden, Germany). G2 buffer is a general lysis buffer containing guanidine hydrochloride, tween and triton X100. For CSF, tissues and plasma obtained from blood samples, $200 \mu \mathrm{L}$ of samples were added to $190 \mu \mathrm{L}$ G2 buffer and $10 \mu \mathrm{L}$ lysozyme $(100 \mathrm{mg} / \mathrm{mL})$. A step of $10 \mathrm{~min}$ at $37^{\circ} \mathrm{C}$ was necessary before DNA extraction. DNA was extracted from $200 \mu \mathrm{L}$ of pretreated sample using EZ1 instruments (Qiagen, Germany) according to the manufacturer's instructions. DNA was then eluted under a volume of $100 \mu \mathrm{L}$. We used non-frozen DNA obtained from fresh samples for the analysis.

Real time PCR was performed in a Smart cycler ${ }^{\circledR}$ (Cepheid, Sunnyvale, USA) with $5 \mu \mathrm{L}$ of DNA, 12.5 $\mu \mathrm{L}$ of Master Mix Premix Ex Taq (Takara, Saint-Germain-en-Laye, France), $2.5 \mu \mathrm{L}$ of Sybr Green 
(Sigma, France), $1 \mu \mathrm{L}$ of each primer at $10 \mu \mathrm{M}$ (LFB1-F 5' -CATTCATGTTTCGAATCATTTCAAA- $3^{\prime}$ and LFB1-R $5^{\prime}$-GGCCCAAGTTCCTTCTAAAAG- $3^{\prime}$ ) and $3 \mu \mathrm{L}$ of water. Thermal cycling conditions were as follows: 1 cycle of $30 \mathrm{~s}$ at $95^{\circ} \mathrm{C}$ followed by 45 cycles of $15 \mathrm{~s}$ at $95^{\circ} \mathrm{C}, 30 \mathrm{~s}$ at $58^{\circ} \mathrm{C}$ and $30 \mathrm{~s}$ at $72{ }^{\circ} \mathrm{C}$. The last step was a ramp up from $58^{\circ} \mathrm{C}$ to $95^{\circ} \mathrm{C}$ by $0.2^{\circ} \mathrm{C} / \mathrm{s}$ to obtain a melting peak curve. Beta-globulin detection was performed on all samples to test for the presence of inhibitors. Our method is regularly subject to performance review via external quality control from the French National Reference Center for Leptospira (Pasteur Institute, Paris, France).

\subsection{Clinical and Biological Data}

Over the study period the cases were identified using the database of the Program for Medicalization of Information System (PMSI) looking for confirmed cases of leptospirosis in patients hospitalized in the Intensive Care Units of our Hospital. Data were collected retrospectively through the computerized medical files of the patients using the hospital medical software: DXlab ${ }^{\circledR}$ (v4.23.30, MEDASYS, Le Plessis-Robinson, France) and Millenium ${ }^{\circledR}$ (v2015.01.19, CERNER, Paris-La défense, France). The data analyzed were age and sex of the patients, clinical and biological symptoms suggestive of leptospirosis and date of events (year, month). Results from molecular biology and serological testing, performed by EIA completed with MAT, were collected and reported for each patient in addition to the outcome of the disease and antimicrobial therapy used.

\section{Results}

\subsection{Epidemiological Data}

Over a seven-year period (January 2011 to January 2018) the PMSI database of Tours University Hospital identified 16 cases of confirmed leptospirosis in adult patients hospitalized in the ICU. Our laboratory received 75 samples of serum, urine and CSF from 34 patients hospitalized in the ICU to test for leptospirosis with a molecular technique. We performed our in-house PCR assay targeting $l f b 1$ on these samples. Among the 34 patients, 15 (44\%) were found positive for leptospirosis involving 33 (44\%) of the 75 samples tested. Only one patient showed negative PCR results but positive serological results.

The median age at diagnosis was 56 years (Table 1). Sex ratio was noticeably in favor of male with 14 out of 16 patients $(87 \%)$. The majority of cases $(13 / 16 ; 81 \%)$ occurred over the summer period from May to September including a peak of 6 cases in July. Only 3 cases (19\%) occurred over the winter period from November to January. The source of contamination was detected in almost every case. The main source of exposure was bathing and swimming in rivers (5 patients, $31 \%$ ). The other included having contact with or drinking stagnant water (4 patients, 25\%), fishing ( 3 patients, $19 \%$ ), hunting (3 patients, 19\%) (one patient having been exposed through both fishing and hunting) and gardening (1 patient, $6 \%$ ). For one patient the source of contamination was not identified, even postmortem. 
Table 1. Main characteristics of patients hospitalized in ICU with a confirmed leptospirosis diagnosis.

\begin{tabular}{|c|c|c|c|c|c|c|c|c|c|c|}
\hline Age & Gender & Date $(\mathrm{M} / \mathrm{Y})$ & Main Symptoms & Biological Data & Samples (Results) & $\begin{array}{c}\text { Delay between First } \\
\text { Symptom and } \\
\text { Sampling (Days) } \\
\end{array}$ & $\begin{array}{l}\text { Duration of ICU } \\
\text { Hospitalization } \\
\text { (Days) } \\
\end{array}$ & $\begin{array}{l}\text { Treatment } \\
\text { Received }\end{array}$ & Outcome & $\begin{array}{l}\text { Epidemiological } \\
\text { Data }\end{array}$ \\
\hline 60 & $\mathrm{M}$ & $\begin{array}{l}\text { September } \\
\quad 2011\end{array}$ & $\begin{array}{l}\text { Fever, myalgia; acute respiratory distress } \\
\text { and acute kidney failure }\end{array}$ & $\begin{array}{l}\text { Creatininemia: } 516 \mu \mathrm{mol} / \mathrm{L} \\
\text { Elevated liver enzymes } \\
\text { Thrombocytopenia: } 81 \mathrm{G} / \mathrm{L}\end{array}$ & $\begin{array}{l}\text { PCR on blood and urine } \\
\text { (positive)/no serology } \\
\text { performed }\end{array}$ & 3 & 1 & Ceftriaxone & Death & $\begin{array}{l}\text { Contact with } \\
\text { stagnant water }\end{array}$ \\
\hline 60 & $\mathrm{~F}$ & April 2012 & $\begin{array}{l}\text { Fever; vomiting; acute respiratory } \\
\text { distress syndrome due to intra-alveolar } \\
\text { hemorrhage, acute kidney failure and } \\
\text { jaundice }\end{array}$ & $\begin{array}{l}\text { Creatininemia: } 405 \mu \mathrm{mol} / \mathrm{L} \\
\text { Elevated liver enzymes } \\
\text { Bilirubinemia: } 341 \mu \mathrm{mol} / \mathrm{L} \\
\text { Thrombocytopenia: } 8 \mathrm{G} / \mathrm{L}\end{array}$ & $\begin{array}{l}\text { PCR on blood, urine, lung and } \\
\text { liver post mortem biopsies } \\
\text { (positive)/serology on day } 9 \\
\text { (positive) }\end{array}$ & 7 & 2 & Ceftriaxone & Death & Unknown \\
\hline 55 & $\mathrm{M}$ & July 2013 & $\begin{array}{c}\text { Fever; myalgia, acute respiratory } \\
\text { distress; acute kidney failure and } \\
\text { jaundice }\end{array}$ & $\begin{array}{l}\text { Creatininemia: } 168 \mu \mathrm{mol} / \mathrm{L} \\
\text { Bilirubinemia: } 706 \mu \mathrm{mol} / \mathrm{L} \\
\text { Thrombocytopenia: } 12 \mathrm{G} / \mathrm{L}\end{array}$ & $\begin{array}{c}\text { PCR on blood and urine } \\
\text { (positive)/serology on day } 6 \\
\text { (negative) }\end{array}$ & 6 & 3 & Ceftriaxone & $\begin{array}{l}\text { Complete } \\
\text { recovery }\end{array}$ & Swimming in a river \\
\hline 20 & M & August 2013 & $\begin{array}{l}\text { Fever; myalgia, acute respiratory } \\
\text { distress with intra alveolar hemorrhage; } \\
\text { acute kidney failure and jaundice }\end{array}$ & $\begin{array}{l}\text { Creatininemia: } 124 \mu \mathrm{mol} / \mathrm{L} \\
\text { Bilirubinemia: } 217 \mu \mathrm{mol} / \mathrm{L} \\
\text { Thrombocytopenia: } 25 \mathrm{G} / \mathrm{L} \\
\end{array}$ & $\begin{array}{c}\text { PCR on blood and urine } \\
\text { (positive)/serology on day } 2 \\
\text { (negative) }\end{array}$ & 2 & 8 & Ceftriaxone & $\begin{array}{l}\text { Complete } \\
\text { recovery }\end{array}$ & $\begin{array}{l}\text { Swimming in a } \\
\text { river/skin lesions }\end{array}$ \\
\hline 43 & $\mathrm{M}$ & June 2014 & $\begin{array}{l}\text { Fever, myalgia, arthralgia, diarrhea, } \\
\text { cutaneous rash; Acute Kidney Failure }\end{array}$ & $\begin{array}{l}\text { Creatininemia: } 140 \mu \mathrm{mol} / \mathrm{L} \\
\text { Elevated liver enzymes } \\
\text { Rhabdomyolysis }\end{array}$ & $\begin{array}{l}\text { PCR on blood (positive) and } \\
\text { urine (negative)/serology on } \\
\text { day } 7 \text { (negative) }\end{array}$ & 4 & 8 & $\begin{array}{l}\text { Ceftriaxone } \\
\text { followed by } \\
\text { Amoxicillin }\end{array}$ & $\begin{array}{l}\text { Complete } \\
\text { recovery }\end{array}$ & $\begin{array}{l}\text { Consumption of } \\
\text { stagnant water }\end{array}$ \\
\hline 39 & $\mathrm{M}$ & July 2014 & Fever and jaundice & $\begin{array}{c}\text { Bilirubinemia: } 53 \mu \mathrm{mol} / \mathrm{L} \\
\text { Elevated liver enzymes } \\
\text { Thrombocytopenia: } 87 \mathrm{G} / \mathrm{L} \\
\end{array}$ & $\begin{array}{l}\text { PCR on blood (positive) no } \\
\text { urine sampling/serology on } \\
\text { day } 8 \text { (negative) }\end{array}$ & 7 & 8 & $\begin{array}{l}\text { Ceftriaxone } \\
\text { followed by } \\
\text { Doxycycline }\end{array}$ & $\begin{array}{l}\text { Complete } \\
\text { recovery }\end{array}$ & Swimming in a river \\
\hline 49 & $\mathrm{M}$ & August 2014 & $\begin{array}{l}\text { Fever, myalgia, diarrhea, acute } \\
\text { respiratory distress with intra-alveolar } \\
\text { hemorrhage requiring oro-tracheal } \\
\text { intubation; acute kidney failure and } \\
\text { jaundice } \\
\end{array}$ & $\begin{array}{c}\text { Creatininemia: } 223 \mu \mathrm{mol} / \mathrm{L} \\
\text { Elevated liver enzyme } \\
\text { Bilirubinemia: } 405 \mu \mathrm{mol} / \mathrm{L} \\
\text { Anemia } \\
\text { Thrombocytopenia: } 10 \mathrm{G} / \mathrm{L} \\
\end{array}$ & $\begin{array}{c}\text { PCR on urine (positive) no } \\
\text { plasma sampling/serology on } \\
\text { day } 7 \text { (negative) and day } 22 \\
\text { (positive) }\end{array}$ & 7 & 14 & Ceftriaxone & $\begin{array}{l}\text { Complete } \\
\text { recovery }\end{array}$ & Fishing \\
\hline 71 & $\mathrm{~F}$ & August 2014 & $\begin{array}{l}\text { Fever, diarrhea, acute kidney failure and } \\
\text { jaundice }\end{array}$ & $\begin{array}{c}\text { Creatininemia: } 164 \mu \mathrm{mol} / \mathrm{L} \\
\text { Elevated liver enzymes } \\
\text { Bilirubinemia: } 278 \mu \mathrm{mol} / \mathrm{L} \\
\text { Thrombocytopenia: } 57 \mathrm{G} / \mathrm{L} \\
\end{array}$ & $\begin{array}{l}\text { PCR on blood and urine } \\
\text { (positive)/no serology } \\
\text { performed }\end{array}$ & 4 & 6 & $\begin{array}{l}\text { Ceftriaxone } \\
\text { followed by } \\
\text { Doxycycline }\end{array}$ & $\begin{array}{l}\text { Complete } \\
\text { recovery }\end{array}$ & $\begin{array}{l}\text { Contact with } \\
\text { stagnant water and } \\
\text { consumption of } \\
\text { water from a well } \\
\end{array}$ \\
\hline 65 & $\mathrm{M}$ & $\begin{array}{l}\text { November } \\
\quad 2014\end{array}$ & Fever, acute kidney failure and jaundice & $\begin{array}{c}\text { Creatininemia: } 411 \mu \mathrm{mol} / \mathrm{L} \\
\text { Elevated liver enzymes } \\
\text { Bilirubinemia: } 46 \mu \mathrm{mml} / \mathrm{L} \\
\text { Thrombocytopenia: } 10 \mathrm{G} / \mathrm{L} \\
\end{array}$ & $\begin{array}{c}\text { PCR on blood and urine } \\
\text { (positive)/serology on day } 30 \\
\text { (positive) }\end{array}$ & 6 & 3 & $\begin{array}{l}\text { Ceftriaxone } \\
\text { followed by } \\
\text { Amoxicillin }\end{array}$ & $\begin{array}{l}\text { Complete } \\
\text { recovery }\end{array}$ & Hunting \\
\hline 58 & M & $\begin{array}{l}\text { December } \\
\quad 2014\end{array}$ & $\begin{array}{l}\text { Fever, myalgia, arthralgia, acute kidney } \\
\text { failure and jaundice }\end{array}$ & $\begin{array}{c}\text { Creatininemia: } 327 \mu \mathrm{mol} / \mathrm{L} \\
\text { Elevated liver enzymes } \\
\text { Bilirubinemia: } 139 \mu \mathrm{mol} / \mathrm{L} \\
\text { Thrombocytopenia: } 83 \mathrm{G} / \mathrm{L} \\
\end{array}$ & $\begin{array}{l}\text { PCR on blood, urine and CSF } \\
\text { (negative)/serology on day } 17 \\
\text { (positive) }\end{array}$ & 10 & 4 & $\begin{array}{l}\text { Amoxicillin } \\
\text { and } \\
\text { Ofloxacin }\end{array}$ & $\begin{array}{l}\text { Complete } \\
\text { recovery }\end{array}$ & Swimming in a river \\
\hline 37 & $\mathrm{M}$ & May 2015 & $\begin{array}{l}\text { Fever, myalgia, rhabdomyolysis, acute } \\
\text { kidney failure }\end{array}$ & $\begin{array}{l}\text { Creatininemia: } 210 \mu \mathrm{mol} / \mathrm{L} \\
\quad \text { Elevated liver enzymes } \\
\text { Thrombocytopenia: } 139 \mathrm{G} / \mathrm{L}\end{array}$ & $\begin{array}{c}\text { PCR on blood (negative) and } \\
\text { urine (positive)/serology on } \\
\text { day } 6 \text { (positive) }\end{array}$ & 6 & 4 & Ceftriaxone & $\begin{array}{l}\text { Complete } \\
\text { recovery }\end{array}$ & Swimming in a river \\
\hline 72 & $\mathrm{M}$ & June 2015 & $\begin{array}{l}\text { Fever, myalgia, acute kidney failure } \\
\text { requiring extra-renal purification, and } \\
\text { jaundice }\end{array}$ & $\begin{array}{c}\text { Creatininemia: } 404 \mu \mathrm{mol} / \mathrm{L} \\
\text { Elevated liver enzymes } \\
\text { Bilirubinemia: } 177 \mu \mathrm{mol} / \mathrm{L} \\
\text { Thrombocytopenia: } 12 \mathrm{G} / \mathrm{L} \\
\text { Rhabdomyolysis }\end{array}$ & $\begin{array}{l}\text { PCR on blood and urine } \\
\text { (positive)/serology on day } 3 \\
\text { (negative) }\end{array}$ & 3 & 8 & Ceftriaxone & $\begin{array}{l}\text { Complete } \\
\text { recovery }\end{array}$ & Hunting \\
\hline
\end{tabular}


Table 1. Cont.

\begin{tabular}{|c|c|c|c|c|c|c|c|c|c|c|}
\hline Age & Gender & Date (M/Y) & Main Symptoms & Biological Data & Samples (Results) & $\begin{array}{l}\text { Delay between First } \\
\text { Symptom and } \\
\text { Sampling (Days) } \\
\end{array}$ & $\begin{array}{l}\begin{array}{l}\text { Duration of ICU } \\
\text { Hospitalization } \\
\text { (Days) }\end{array} \\
\end{array}$ & $\begin{array}{l}\text { Treatment } \\
\text { Received }\end{array}$ & Outcome & $\begin{array}{l}\text { Epidemiological } \\
\text { Data }\end{array}$ \\
\hline 61 & $\mathrm{M}$ & July 2015 & $\begin{array}{l}\text { Fever, myalgia, acute respiratory distress } \\
\text { requiring oro-tracheal intubation, acute } \\
\text { kidney failure with hematuria, and } \\
\text { jaundice }\end{array}$ & $\begin{array}{c}\text { Creatininemia: } 656 \mu \mathrm{mol} / \mathrm{L} \\
\text { Elevated liver enzymes } \\
\text { Bilirubinemia: } 406 \mu \mathrm{mol} / \mathrm{L} \\
\text { Thrombocytopenia: } 15 \mathrm{G} / \mathrm{L} \\
\text { Anemia } \\
\end{array}$ & $\begin{array}{l}\text { PCR on blood and urine } \\
\text { (positive)/no serology } \\
\text { performed }\end{array}$ & 5 & 9 & $\begin{array}{l}\text { Ceftriaxone } \\
\text { followed by } \\
\text { Amoxicillin }\end{array}$ & $\begin{array}{l}\text { Complete } \\
\text { recovery }\end{array}$ & Hunting and fishing \\
\hline 51 & M & July 2015 & $\begin{array}{l}\text { Fever, myalgia, arthralgia, acute kidney } \\
\text { failure and jaundice }\end{array}$ & $\begin{array}{c}\text { Creatininemia: } 257 \mu \mathrm{mol} / \mathrm{L} \\
\text { Elevated liver enzymes } \\
\text { Bilirubinemia: } 31 \mu \mathrm{mol} / \mathrm{L} \\
\text { Thrombocytopenia: } 102 \mathrm{G} / \mathrm{L} \\
\end{array}$ & $\begin{array}{l}\text { PCR on blood (negative) and } \\
\text { urine (positive)/serology on } \\
\text { day } 6 \text { (negative) }\end{array}$ & 6 & 3 & Ceftriaxone & $\begin{array}{l}\text { Complete } \\
\text { recovery }\end{array}$ & Fishing \\
\hline 15 & M & $\begin{array}{l}\text { September } \\
2016\end{array}$ & $\begin{array}{l}\text { Fever, myalgia, arthralgia, acute kidney } \\
\text { failure and jaundice }\end{array}$ & $\begin{array}{l}\text { Creatininemia: } 137 \mu \mathrm{mol} / \mathrm{L} \\
\text { Elevated liver enzymes } \\
\text { Bilirubinemia: } 52 \mu \mathrm{mol} / \mathrm{L} \\
\text { Thrombocytopenia: } 22 \mathrm{G} / \mathrm{L}\end{array}$ & $\begin{array}{l}\text { PCR on blood (positive) and } \\
\text { urine (negative)/no serology } \\
\text { performed }\end{array}$ & 5 & 4 & Ceftriaxone & $\begin{array}{l}\text { Complete } \\
\text { recovery }\end{array}$ & Swimming in a river \\
\hline 62 & $\mathrm{M}$ & January 2017 & $\begin{array}{l}\text { Fever, myalgia, arthralgia, } \\
\text { rhabdomyolysis, acute kidney failure } \\
\text { and jaundice }\end{array}$ & Creatininemia: $331 \mu \mathrm{mol} / \mathrm{L}$ & $\begin{array}{l}\text { PCR on blood (negative) and } \\
\text { urine (positive)/no serology } \\
\text { performed }\end{array}$ & 8 & 2 & Ceftriaxone & $\begin{array}{l}\text { Complete } \\
\text { recovery }\end{array}$ & Gardening \\
\hline
\end{tabular}




\subsection{Clinical and Biological Characteristics}

Although the clinical presentation was often typical, especially among severe cases when ICU admission was needed, we noticed disparities in the clinical features (Table 1). All patients (16/16) presented with fever and thrombocytopenia. The majority $(15 / 16 ; 94 \%)$ presented with kidney failure, including one patient who required renal replacement therapy. Jaundice was observed in 13 patients $(81 \%)$ and $8(50 \%)$ showed elevated liver enzymes. The characteristic association of jaundice and kidney failure defined as Weil's disease was observed in 12 cases (75\%). There were also 12 patients $(75 \%)$ describing arthralgia and myalgia but only 4 presented $(25 \%)$ with rhabdomyolysis. Acute respiratory failure was observed in 6 patients (37\%) and digestive disorders including diarrhea and vomiting in 5 patients (31\%).

The outcome was favorable in 14 out of the 16 cases $(87 \%)$ with complete recovery following adequate antimicrobial therapy. Among these 14 patients, 8 patients $(57 \%)$ had been treated with ceftriaxone only, while 3 patients (19\%) were switched to second-line amoxicillin per os and $2(12 \%)$ received second-line oral therapy with doxycycline. One patient received amoxicillin followed by doxycycline. Each of these 14 patients completed a course of at least 10 days of antibiotic therapy. The other 2 patients $(12 \%)$ died of multiple organ failure and although they received ceftriaxone, death occurred before 10 days of treatment.

\subsection{Leptospirosis Sampling Results}

Samples from the 16 patients have been tested with our in-house PCR assay targeting lfbl. Among them, 14 patients had both urine and blood samples collected while 2 patients only had one collected. We divided the patients into three distinct groups according to the in-house PCR assay results on blood and urine samples. Eight patients (50\%) tested positive on both blood and urine. The median duration between first symptoms and positive results in this group was 4.5 days $( \pm 2.5)$. Four patients $(25 \%)$ tested positive only on the urine samples while $3(19 \%)$ tested positive only on the blood samples. Median duration between first symptoms and positive results in these groups was 6 days $( \pm 2)$ and 4.5 days $( \pm 0.5)$, respectively.

Considering the samples independently, PCR was positive on blood in 11 patients and on urine in 12 patients (out of the 15 patients showing at least one positive PCR result (Figure 1)). The median duration between the beginning of symptoms and positive result of PCR on blood samples was 5 days (range 2-7) versus 6 days (range 2-8) on urine samples.

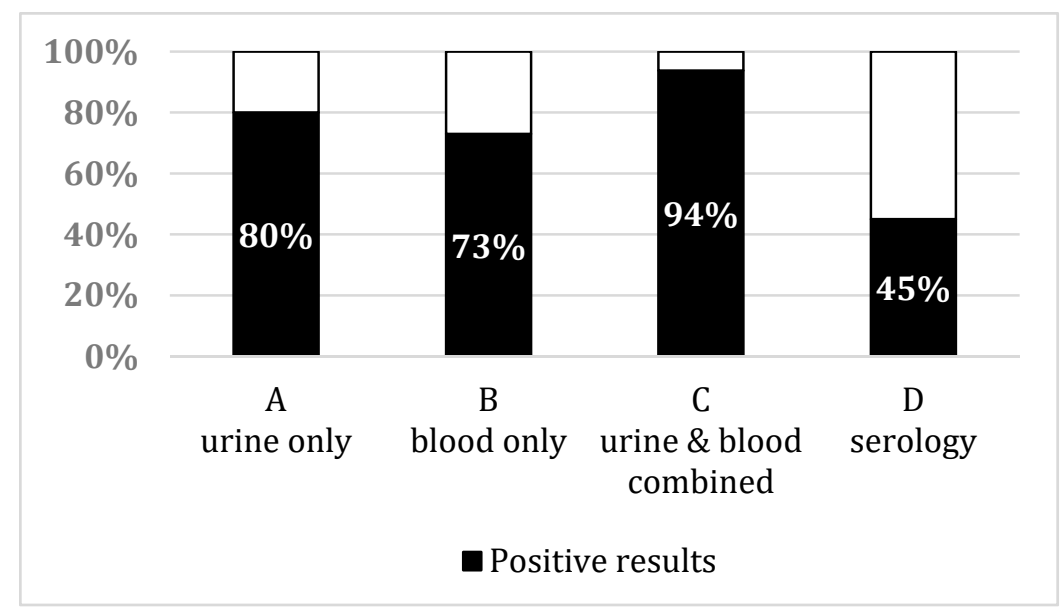

Figure 1. Percentage of leptospirosis diagnosis confirmed in our patients based on positive PCR results among: (A) Urine samples only, (B) blood samples only, (C) when combining urine and/or blood for each patient. The percentage of positive serology results among all serological samples is given in (D) as a comparison. 
Among the 16 patients, 11 (69\%) had serological testing for leptospirosis. Median duration between first symptoms and sampling was 7 days (range 2-30). Four patients presented with positive serology on the first sample and one presented with seroconversion over a period of 15 days, 6 patients showed negative results. Median duration between first symptoms and sampling was 17 days (range 6-30) for positive results and 6 days (range 2-8) for negative results. One patient was diagnosed with serology only. Although blood, urine and CSF samples from this patient had been tested by PCR 10 days after the beginning of the symptoms, PCR results were negative on all the samples. The CSF in this case was probably tested by excess because patient presented headache without a true meningitis syndrome. However, serology performed on blood on Day 17, after the first symptoms, allowed the diagnosis of leptospirosis.

\section{Discussion}

Leptospirosis remains a worldwide public health concern with many cases each year. Even though its burden is higher in tropical and subtropical areas, developed countries have experienced major outbreaks or abnormally high prevalence over the last decade. Many fear that rapid urbanization in developing countries and global warning, along with natural disasters (flooding, massive earthquake, hurricanes, etc.), will contribute to the spread of this disease. Moreover, numerous reports mention the extension of the animal reservoir in different locations worldwide $[18,19]$ as well as the identification of new strains of Leptospira including potentially pathogenic strains [20]. This emphasizes the need for monitoring and prevention to achieve disease control.

Efforts should also be focused on diagnosis. Indeed, life-threatening forms of leptospirosis rapidly progress from fever to multiple organ failure. The cases described in this study presented severe forms of leptospirosis. This can be explained by the recruitment of patients hospitalized in the ICU. However, $87 \%$ experienced full recovery after receiving adequate antibiotic therapy along with supportive care initiated rapidly after diagnosis. This underlines the importance of a quick and accurate diagnosis to give the patient the best chances of recovery.

Several works have presented the successful use of PCR in early diagnosis of leptospirosis [9-11,18]. The findings of this study are consistent with those studies. Indeed, only five (31\%) patients presented positive serological results among those tested with a median duration between first symptoms and positive results of 17 days. Whereas, as expected, infected patients with negative serology results presented a median duration of 6 days between first symptoms and sampling.

However, the majority of our patients ( 15 out of $16,94 \%$ ) were diagnosed early through PCR. Indeed, median duration between onset of symptoms and positive results of PCR was 4.5 days. When taken independently, these durations were 5 and 6 days for blood and urine samples, respectively. The samples of the only patient with negative PCR results were collected 10 days after the onset of the symptoms, which may explain the negativity. This delay of positivity is concordant with results found in previous studies $[10,21]$. Thus, even though the number of patients is limited, it appears that PCR shows a higher diagnostic sensibility than serological testing with $94 \%$ against $45 \%$ of positive results. These results need to be confirmed on a larger number of patients, but they emphasize the potential of molecular testing through PCR for an early diagnosis, in comparison to serological testing.

Interestingly, only eight patients were found to have positive results for both urine and blood samples while four were diagnosed through urine and three through blood sample positivity only. Performing PCR on samples from both anatomical sites (blood and urine) allowed the diagnosis of 15 patients, while only 11 patients would have been diagnosed if only tested on blood and 12 if only tested on urine (Figure 1). These results are in agreement with a previous work from Esteves et al. where main cases were diagnosed at an early stage of the infection corresponding to dissemination and kidney colonization [22]. Thus, sampling on only one site would have left respectively 4 or 3 patients, respectively, with negative PCR results. Even though the number of patients was low, these results suggest that sampling both sites for each patient improved the number of leptospirosis cases diagnosed. 
Persistent shedding of Leptospira in the urine of the infected hosts is well known [3,4]. Diagnosis of leptospirosis through PCR on urine samples has already been described and is often used in animals for monitoring purposes $[16,23,24]$. However, some recent studies in humans showed only PCR results on blood samples $[10,21,25]$ while acknowledging the potential of urine sampling to improve sensibility [21]. A recent study on leptospirosis cases in 79 French Metropolitan ICUs showed that $53 \%$ of patients were diagnosed by PCR on blood while only $11 \%$ were diagnosed by PCR on urine samples [26]. Even though the number of PCR tests performed on the different type of samples was not indicated, this study suggests that urine sampling was not as frequent as blood sampling for PCR testing. In this context, our study, consistently with others, underlines the interest of collecting both urine and blood samples early in patients with symptoms of leptospirosis.

\section{Conclusions}

In conclusion, we highlight in this study the importance of early diagnosis of leptospirosis, which can be obtained with great sensitivity through PCR. We also underline that collecting urine samples along with blood samples might improve the sensitivity and provide a more accurate diagnosis. Further studies are needed to precisely determine the optimal time of sampling blood and urine to confirm diagnosis of leptospirosis. Earlier seems to be best for blood samples, and urine may shift in time. Nevertheless, both seem unavoidable.

Author Contributions: O.B. and P.L. collected the data and wrote the manuscript. A.P., C.L.B. and P.L. performed biological analysis. S.E. treated the patients. All authors have read and agreed to the published version of the manuscript.

Funding: This research did not receive any specific grant from funding agencies in the public, commercial, or not-for-profit sectors.

Acknowledgments: We are very grateful to Mathieu Picardeau from the French National Reference Center for Leptospirosis who provided us with quality control samples.

Conflicts of Interest: The authors declare no conflict of interest.

\section{References}

1. Costa, F.; Hagan, J.E.; Calcagno, J.; Kane, M.; Torgerson, P.; Martinez-Silveira, M.S.; Stein, C.; Abela-Ridder, B.; Ko, A.I. Global Morbidity and Mortality of Leptospirosis: A Systematic Review. PLoS Negl. Trop. Dis. 2015, 9, e0003898. [CrossRef]

2. Baranton, G.; Postic, D. Trends in leptospirosis epidemiology in France. Sixty-six years of passive serological surveillance from 1920 to 2003. Int. J. Infect. Dis. 2006, 10, 162-170. [CrossRef] [PubMed]

3. Levett, P.N. Leptospirosis. Clin. Microbiol. Rev. 2001, 14, 296-326. [CrossRef] [PubMed]

4. Haake, D.A.; Levett, P.N. Leptospirosis in humans. Curr. Top. Microbiol. Immunol. 2015, 387, 65-97. [PubMed]

5. Martins, M.G.; Matos, K.T.; da Silva, M.V.; de Abreu, M.T. Ocular manifestations in the acute phase of leptospirosis. Ocul. Immunol. Inflamm. 1998, 6, 75-79. [CrossRef]

6. Haute Autorité de Santé-Diagnostic Biologique de la Leptospirose. Available online: https://www.has-sante. fr/portail/jcms/c_1084168/fr/diagnostic-biologique-de-la-leptospirose (accessed on 31 March 2019).

7. World Health Organization. Human Leptospirosis: Guidance for Diagnosis, Surveillance and Control. 2003. Available online: https://apps.who.int/iris/handle/10665/42667 (accessed on 17 July 2020).

8. Merien, F.; Baranton, G.; Perolat, P. Comparison of polymerase chain reaction with microagglutination test and culture for diagnosis of leptospirosis. J. Infect. Dis. 1995, 172, 281-285. [CrossRef]

9. Bourhy, P.; Bremont, S.; Zinini, F.; Giry, C.; Picardeau, M. Comparison of real-time PCR assays for detection of pathogenic Leptospira spp. in blood and identification of variations in target sequences. J. Clin. Microbiol. 2011, 49, 2154-2160. [CrossRef] 
10. Agampodi, S.B.; Matthias, M.A.; Moreno, A.C.; Vinetz, J.M. Utility of Quantitative Polymerase Chain Reaction in Leptospirosis Diagnosis: Association of Level of Leptospiremia and Clinical Manifestations in Sri Lanka. Clin. Infect. Dis. 2012, 54, 1249-1255. [CrossRef]

11. Goarant, C.; Laumond-Barny, S.; Perez, J.; Vernel-Pauillac, F.; Chanteau, S.; Guigon, A. Outbreak of leptospirosis in New Caledonia: Diagnosis issues and burden of disease. Trop. Med. Int. Health 2009, 14, 926-929. [CrossRef]

12. Pailhoriès, H.; Buzelé, R.; Picardeau, M.; Robert, S.; Mercier, E.; Mereghetti, L.; Lanotte, P. Molecular characterization of Leptospira sp by multilocus variable number tandem repeat analysis (MLVA) from clinical samples: A case report. Int. J. Infect. Dis. 2015, 37, 119-121. [CrossRef]

13. Slack, A.; Symonds, M.; Dohnt, M.; Harris, C.; Brookes, D.; Smythe, L. Evaluation of a modified Taqman assay detecting pathogenic Leptospira spp. against culture and Leptospira-specific IgM enzyme-linked immunosorbent assay in a clinical environment. Diagn. Microbiol. Infect. Dis. 2007, 57, 361-366. [CrossRef] [PubMed]

14. Ahmed, A.; Engelberts, M.F.M.; Boer, K.R.; Ahmed, N.; Hartskeerl, R.A. Development and validation of a real-time PCR for detection of pathogenic leptospira species in clinical materials. PLoS ONE 2009, 4, e7093. [CrossRef] [PubMed]

15. Thaipadunpanit, J.; Chierakul, W.; Wuthiekanun, V.; Limmathurotsakul, D.; Amornchai, P.; Boonslip, S.; Smythe, L.D.; Limpaiboon, R.; Hoffmaster, A.R.; Day, N.P.J.; et al. Diagnostic Accuracy of Real-Time PCR Assays Targeting 16S rRNA and lipl32 Genes for Human Leptospirosis in Thailand: A Case-Control Study. PLoS ONE 2011, 6, e16236. [CrossRef] [PubMed]

16. Villumsen, S.; Pedersen, R.; Borre, M.B.; Ahrens, P.; Jensen, J.S.; Krogfelt, K.A. Novel TaqMan ${ }^{\circledR}$ PCR for detection of Leptospira species in urine and blood: Pit-falls of in silico validation. J. Microbiol. Methods 2012, 91, 184-190. [CrossRef]

17. Merien, F.; Portnoi, D.; Bourhy, P.; Charavay, F.; Berlioz-Arthaud, A.; Baranton, G. A rapid and quantitative method for the detection of Leptospira species in human leptospirosis. FEMS Microbiol. Lett. 2005, 249, 139-147. [CrossRef]

18. Guernier, V.; Lagadec, E.; Cordonin, C.; Le Minter, G.; Gomard, Y.; Pagès, F.; Jaffar-Bandjee, M.-C.; Michault, A.; Tortosa, P.; Dellagi, K. Human Leptospirosis on Reunion Island, Indian Ocean: Are Rodents the (Only) Ones to Blame? PLoS Negl. Trop. Dis. 2016, 10, e0004733. [CrossRef]

19. Fornazari, F.; Langoni, H.; Marson, P.M.; Nóbrega, D.B.; Teixeira, C.R. Leptospira reservoirs among wildlife in Brazil: Beyond rodents. Acta Trop. 2018, 178, 205-212. [CrossRef]

20. Thibeaux, R.; Iraola, G.; Ferrés, I.; Bierque, E.; Girault, D.; Soupé-Gilbert, M.-E.; Picardeau, M.; Goarant, C. Deciphering the unexplored Leptospira diversity from soils uncovers genomic evolution to virulence. Microb. Genom. 2018, 4, e000144. [CrossRef]

21. Hochedez, P.; Escher, M.; Decoussy, H.; Pasgrimaud, L.; Martinez, R.; Rosine, J.; Théodose, R.; Bourhy, P.; Picardeau, M.; Olive, C.; et al. Outbreak of leptospirosis among canyoning participants, Martinique, 2011. Euro. Surveill. 2013, 18, 20472.

22. Esteves, L.M.; Bulhões, S.M.; Branco, C.C.; Carreira, T.; Vieira, M.L.; Gomes-Solecki, M.; Mota-Vieira, L. Diagnosis of Human Leptospirosis in a Clinical Setting: Real-Time PCR High Resolution Melting Analysis for Detection of Leptospira at the Onset of Disease. Sci. Rep. 2018, 8, 9213. [CrossRef]

23. Bal, A.E.; Gravekamp, C.; Hartskeerl, R.A.; De Meza-Brewster, J.; Korver, H.; Terpstra, W.J. Detection of leptospires in urine by PCR for early diagnosis of leptospirosis. J. Clin. Microbiol. 1994, 32, 1894-1898. [CrossRef] [PubMed]

24. Dadon, Y.; Haas, E.J.; Kaliner, E.; Anis, E.; Singer, S.R.; Atiya-Nasagi, Y.; Cohen-Dar, M.; Avramovich, E.; King, R.; Sued, O.; et al. Outbreak of human leptospirosis linked to contaminated water bodies in Northern Israel, June to August 2018. Euro Surveill. 2018, 23, 180486. [CrossRef] [PubMed] 
25. Riediger, I.N.; Stoddard, R.A.; Ribeiro, G.S.; Nakatani, S.M.; Moreira, S.D.R.; Skraba, I.; Biondo, A.W.; Reis, M.G.; Hoffmaster, A.R.; Vinetz, J.M.; et al. Rapid, actionable diagnosis of urban epidemic leptospirosis using a pathogenic Leptospira lipL32-based real-time PCR assay. PLoS Negl. Trop. Dis. 2017, 11, e0005940. [CrossRef] [PubMed]

26. Miailhe, A.-F.; Mercier, E.; Maamar, A.; Lacherade, J.-C.; Le Thuaut, A.; Gaultier, A.; Asfar, P.; Argaud, L.; Ausseur, A.; Ben Salah, A.; et al. Severe leptospirosis in non-tropical areas: A nationwide, multicentre, retrospective study in French ICUs. Intensive Care Med. 2019, 45, 1763-1773. [CrossRef] [PubMed]

(C) 2020 by the authors. Licensee MDPI, Basel, Switzerland. This article is an open access article distributed under the terms and conditions of the Creative Commons Attribution (CC BY) license (http://creativecommons.org/licenses/by/4.0/). 